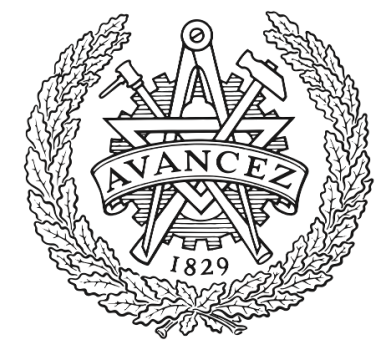

CHALMERS

UNIVERSITY OF TECHNOLOGY

\title{
Investigation of AgGaSe2 as a Wide Gap Solar Cell Absorber
}

Downloaded from: https://research.chalmers.se, 2023-04-26 13:32 UTC

Citation for the original published paper (version of record):

Larsen, J., Donzel-Gargand, O., Sopiha, K. et al (2021). Investigation of AgGaSe2 as a Wide Gap Solar Cell Absorber. ACS Applied Energy Materials, 4(2): 1805-1814. http://dx.doi.org/10.1021/acsaem.0c02909

N.B. When citing this work, cite the original published paper. 


\title{
Investigation of $\mathrm{AgGaSe}_{2}$ as a Wide Gap Solar Cell Absorber
}

\author{
Jes K. Larsen,* Olivier Donzel-Gargand, Kostiantyn V. Sopiha, Jan Keller, Kristina Lindgren, \\ Charlotte Platzer-Björkman, and Marika Edoff
}

Cite This: ACS Appl. Energy Mater. 2021, 4, 1805-1814

Read Online

ACCESS | W W Metrics \& More | 国 Article Recommendations | st Supporting Information

ABSTRACT: The compound $\mathrm{AgGaSe}_{2}$ has received limited attention as a potential wide gap solar cell material for tandem applications, despite its suitable band gap. This study aims to investigate the potential of this material by deposition of thin films by co-evaporation and production of solar cell devices. Since $\mathrm{AgGaSe}_{2}$ has a very low tolerance to off-stoichiometry, reference materials of possible secondary phases in the $\mathrm{Ag}_{2} \mathrm{Se}-\mathrm{Ga}_{2} \mathrm{Se}_{3}$ system were also produced. Based on these samples, it was concluded that X-ray diffraction is suited to distinguish the phases in this material system. An attempt to use Raman spectroscopy to

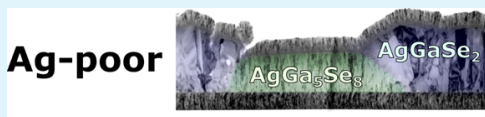
identify secondary phases was less successful. Devices were produced using absorbers

Ag-rich

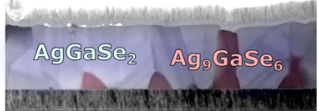
containing the secondary phases likely formed during co-evaporation. When grown under slightly $\mathrm{Ag}$-rich conditions, the $\mathrm{Ag}_{9} \mathrm{GaSe}_{6}$ secondary phase was present along with $\mathrm{AgGaSe}_{2}$, which resulted in devices being shunted under illumination. When absorbers were grown under $\mathrm{Ag}$-deficient conditions, the $\mathrm{AgGa}_{5} \mathrm{Se}_{8}$ secondary phase was observed, making the device behavior dependent on the processing route. Deposition with a three-stage evaporation (Ag-poor, Ag-rich, and $\mathrm{Ag}$-poor) resulted in $\mathrm{AgGa}_{5} \mathrm{Se}_{8}$ layers at both front and back surfaces, leading to charge carrier blocking in devices. Deposition of the absorber with a one-stage process, on the other hand, caused the formation of $\mathrm{AgGa}_{5} \mathrm{Se}_{8}$ locally extended through the entire film, but no continuous layer was found. As a consequence, these devices were not blocking and achieved an efficiency of up to $5.8 \%$, which is the highest reported to date for $\mathrm{AgGaSe}_{2}$ solar cells.

KEYWORDS: thin film solar cells, wide gap solar absorber, $\mathrm{AgGaSe} e_{2}$ phase separation, Raman spectroscopy

\section{INTRODUCTION}

Thin-film solar cells based on $\mathrm{Cu}(\mathrm{In}, \mathrm{Ga})(\mathrm{Se}, \mathrm{S})_{2}$ (CIGS(e)) absorbers have reached efficiencies up to $23.4 \%$ for laboratoryscale devices, ${ }^{1}$ demonstrating the great potential of chalcopyrite absorber materials. In order to reach even higher efficiency, development of multijunction structures is a possible way forward. For a four-terminal tandem with a silicon bottom cell, it is theoretically possible to reach efficiencies around $44 \%$ using a top cell with a band gap in the range $1.6-2.0 \mathrm{eV}$. $^{2}$ $\mathrm{AgGaSe}_{2}$ has been reported to have a band gap in the range $1.6^{3}-1.8 \mathrm{eV}^{4}$ and would therefore be an interesting candidate as a top cell in combination with a Si or CIGS(e) bottom cell. The advantage of $\mathrm{AgGaSe}_{2}$ compared to other wide band gap materials such as $\mathrm{CuGaSe}_{2}$ or $\mathrm{Cu}_{2} \mathrm{ZnSnS}_{4}$ is that the conduction band alignment with $\mathrm{CdS}$ is spike-like, ${ }^{5}$ making it possible to substitute CIGS(e) in the typical device architecture without change in buffer layer material.

Reports on solar cells based on $\mathrm{AgGaSe}_{2}$ are very limited. The highest efficiency of $4.5 \%$ based on a $\mathrm{AgGaSe}_{2} / \mathrm{CdS}$ heterojunction was published by Murthy et al. already in $1990 .^{6}$ The same efficiency was reached by Yamada et al. in 2006. ${ }^{7}$ To the best of our knowledge, better performing $\mathrm{AgGaSe}_{2}$ solar cells have not been reported since 2006. Unlike pure $\mathrm{AgGaSe}_{2}$, indium-alloyed $\mathrm{Ag}(\mathrm{In}, \mathrm{Ga}) \mathrm{Se}_{2}$ has been investigated in more detail. Nakada et al. achieved a conversion efficiency of $9.3 \%$ for devices with $[\mathrm{Ga}] /([\mathrm{Ga}]+[\mathrm{In}])=0.8$. $^{8}$ An efficiency of $10.7 \%$ was reported for $\mathrm{Ag}(\mathrm{In}, \mathrm{Ga}) \mathrm{Se}_{2}$ with
$[\mathrm{Ga}] /([\mathrm{Ga}]+[\mathrm{In}])=0.75$ after air-annealing the completed solar cell for $5 \mathrm{~min}$ at $200{ }^{\circ} \mathrm{C}$. ${ }^{9}$ It should be noted, however, that these results are not directly comparable with $\mathrm{AgGaSe}_{2}$ because In alloying decreases the material band gap, thereby increasing its Shockley-Queisser (SQ) limit. Aspects that have been investigated for $\mathrm{Ag}(\mathrm{In}, \mathrm{Ga}) \mathrm{Se}_{2}$ solar cells include the formation of non-Ohmic back contact due to the absence of $\mathrm{MoSe}_{2},{ }^{10,11}$ segregation of Ag during three-stage growth, ${ }^{12,13}$ and peculiarities of the effect of $\mathrm{Na}{ }^{14,15}$

There was interest in $\mathrm{AgGaSe}_{2}$ for applications in infrared nonlinear optical devices already four decades ago. ${ }^{16,17}$ Scattering centers due to what was described as $\mathrm{Ga}_{2} \mathrm{Se}_{3}$-rich precipitates were however often observed, which was problematic for optical applications. ${ }^{18-21}$ In the pseudobinary-phase diagram of the $\mathrm{Ag}_{2} \mathrm{Se}-\mathrm{Ga}_{2} \mathrm{Se}_{3}$ system published by Mikkelsen, the precipitates were related to a phase with an approximate composition of $\mathrm{AgGa}_{7} \mathrm{Se}_{11} \cdot{ }^{20}$ The single-phase region of the chalcopyrite $\mathrm{AgGaSe}_{2}$ phase was determined to be relatively narrow, spanning the range $0.96 \leq[\mathrm{Ag}] /[\mathrm{Ga}] \leq 1$ at $660{ }^{\circ} \mathrm{C}$,

Received: November 23, 2020

Accepted: January 21, 2021

Published: February 2, 2021 
but decreasing with decreasing temperature. ${ }^{20}$ Consequently, the presence of $\mathrm{Ga}_{2} \mathrm{Se}_{3}$-rich inclusions is hard to avoid even in nearly perfectly stoichiometric $\mathrm{AgGaSe}_{2}$ after cooling down. $\mathrm{Kim}$ et al. even described the presence of $\mathrm{Ga}_{2} \mathrm{Se}_{3}$-rich precipitates as being unavoidable for Bridgman-grown $\mathrm{AgGaSe}_{2} \cdot{ }^{19} \mathrm{~A}$ more recent publication attributes this phase to $\mathrm{AgGa}_{5} \mathrm{Se}_{8}{ }^{22}$ Irrespective of the chemical composition, it is known that this " $\mathrm{Ga}_{2} \mathrm{Se}_{3}$-rich" phase has tetragonal (zincblende-derived) crystal symmetry, which identifies it as an ordered vacancy compound (OVC), similar to the $\mathrm{Cu}$-poor phases observed in the $\mathrm{Cu}_{2} \mathrm{Se}-\mathrm{Ga}_{2} \mathrm{Se}_{3}$ and $\mathrm{Cu}_{2} \mathrm{Se}-\mathrm{In}_{2} \mathrm{Se}_{3}$ systems. The existence of two types of OVCs, $\mathrm{Cu}(\mathrm{In}, \mathrm{Ga})_{3} \mathrm{Se}_{5}{ }^{23}$ and $\mathrm{Cu}(\mathrm{In}, \mathrm{Ga})_{5} \mathrm{Se}_{8},{ }^{24}$ has been unequivocally established by a number of studies on $\mathrm{Cu}_{2} \mathrm{Se}-(\mathrm{In}, \mathrm{Ga})_{2} \mathrm{Se}_{3}$ systems. ${ }^{25,26}$ Additionally, several other OVCs (e.g., $\mathrm{Cu}_{2} \mathrm{In}_{4} \mathrm{Se}_{7}$ ) have been proposed, ${ }^{27}$ although independent attempts to verify their existence were unsuccessful. ${ }^{27}$ For Ag-based systems, the formation of $\mathrm{AgIn}_{5} \mathrm{Se}_{8}{ }^{28}$ and $\mathrm{AgGa}_{5} \mathrm{Se}_{8}{ }^{22}$ has been suggested based on X-ray diffraction (XRD). $\mathrm{AgIn}_{3} \mathrm{Se}_{5}$ has been reported in nanocrystals as well, ${ }^{29}$ but $\mathrm{AgGa}_{3} \mathrm{Se}_{5}$ has never been observed.

In the Ag-rich part of the phase diagram, Mikkelsen reports $\mathrm{Ag}_{9} \mathrm{GaSe}_{6}$ inclusions along with $\mathrm{AgGaSe}_{2}$ and sets $[\mathrm{Ag}] /[\mathrm{Ga}]=$ 1 as the phase boundary. Other phases that are present in the phase diagram are $\mathrm{Ag}_{2} \mathrm{Se}$ and $\mathrm{Ga}_{2} \mathrm{Se}_{3}$, but these are only expected for $[\mathrm{Ag}] /[\mathrm{Ga}]>9$ and $[\mathrm{Ag}] /[\mathrm{Ga}]<0.14$, respectively. ${ }^{20}$ Due to the very narrow single-phase region of $\mathrm{AgGaSe}_{2}$, secondary phases can easily form, and it is important to be able to detect and control them when making thin-film solar cells. It is furthermore important to know their properties in order to understand how their presence affects the device.

Commonly used tools to help identify secondary phases in thin films are Raman spectroscopy and XRD. In an attempt to aid identification, we have gathered the properties of the expected phases available in the literature, as shown in Table 1.

Table 1. Properties of the Phases Appearing in the $\mathrm{Ag}_{2} \mathrm{Se}-$ $\mathrm{Ga}_{2} \mathrm{Se}_{3}$ System Found in the Literature ${ }^{a}$

\begin{tabular}{|c|c|c|c|}
\hline phase & space group & Raman signature $\left[\mathrm{cm}^{-1}\right]$ & $\begin{array}{c}\text { band gap } \\
{[\mathrm{eV}]}\end{array}$ \\
\hline $\mathrm{Ga}_{2} \mathrm{Se}_{3}$ & $\begin{array}{l}C c(9)^{30} / F \overline{4} 3 m \\
(216)^{31}\end{array}$ & $\begin{array}{l}105,118,155,250, \\
290^{32,33}\end{array}$ & $2.3^{34}$ \\
\hline $\mathrm{AgGa}_{5} \mathrm{Se}_{8}$ & $P \overline{4} 2 m(111)^{22}$ & & $2.1^{22}$ \\
\hline $\mathrm{AgGaSe}_{2}$ & $I \overline{4} 2 d(122)^{35}$ & $\begin{array}{l}136,159,178,238,249 \\
276^{36,37}\end{array}$ & $1.6^{3}-1.8^{4}$ \\
\hline $\mathrm{Ag}_{9} \mathrm{GaSe}_{6}$ & $\begin{array}{l}P 2_{1} 3(198)^{38} / \bar{F} \overline{3} m \\
\quad(216)^{39}\end{array}$ & & $0.56^{39}$ \\
\hline $\mathrm{Ag}_{2} \mathrm{Se}$ & $\begin{array}{l}P 2_{1} 2_{1} 2_{1}(19)^{40} / \operatorname{Im} \overline{3} m \\
\quad(229)^{41}\end{array}$ & $155,170,230^{42,43}$ & $0-0.16^{44}$ \\
\hline
\end{tabular}

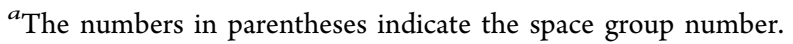

While the space groups and lattice constants of all phases are already available, the Raman spectra of $\mathrm{AgGa}_{5} \mathrm{Se}_{8}$ and $\mathrm{Ag}_{9} \mathrm{GaSe}_{6}$ have not been reported to our knowledge. It is also important to be aware that several of the compounds can form different polymorphs depending on the growth method and conditions. This is especially notable for $\mathrm{Ag}_{9} \mathrm{GaSe}_{6}$ that has a phase transition from $\beta-\mathrm{Ag}_{9} \mathrm{GaSe}_{6}$ (space group $P 2_{1} 3$ ) to $\alpha$ $\mathrm{Ag}_{9} \mathrm{GaSe}_{6}$ (space group $\mathrm{F} 43 \mathrm{~m}$ ) at $281 \mathrm{~K}^{45}$ and $\mathrm{Ag}_{2} \mathrm{Se}$ that has a phase transition from $\alpha-\mathrm{Ag}_{2} \mathrm{Se}$ (orthorhombic $P 2_{1} 2_{1} 2_{1}$ ) to $\beta$ $\mathrm{Ag}_{2} \mathrm{Se}$ (cubic $\operatorname{Im} \overline{3} \mathrm{~m}$ ) at $403 \mathrm{~K}^{46}$ In order to identify polymorphs formed during the co-evaporation process, we deposited reference films for each of these phases and determined their Raman spectra. Since it is not easy to avoid the formation of secondary phases in this material system, it is also interesting to investigate the impact of secondary phases on device behavior. This is done by characterizing a Ag-rich device containing $\mathrm{Ag}_{9} \mathrm{GaSe}_{6}$ and two Ag-poor devices containing $\mathrm{AgGa}_{5} \mathrm{Se}_{8}$.

\section{EXPERIMENTAL SECTION}

2.1. Sample Preparation. All samples in this study were deposited on soda-lime glass (SLG) substrates by co-evaporation. The SLG was coated with Mo by sputtering prior to absorber layer growth for samples used for device fabrication and most characterizations. A piece of uncoated glass was included during the deposition and used for optical transmittance and sheet resistance measurements. The substrate temperature during the first $2 \mathrm{~min}$ of deposition was $500{ }^{\circ} \mathrm{C}$. The substrate temperature was then increased to $550{ }^{\circ} \mathrm{C}$ with a ramp rate of $18{ }^{\circ} \mathrm{C} / \mathrm{min}$ and kept constant for the remaining deposition. With one exception, all samples were deposited with a one-stage process where the evaporation rates of all elements were kept constant throughout the process. For comparison, one sample was produced via a three-stage evaporation profile adopted from CIGS(e) deposition. ${ }^{47}$ During this process, the material was grown with $\mathrm{Ag}$ deficiency in the first stage, followed by a Ag-rich stage, and finally, a Ag-poor stage at the end of the deposition. It was intended to produce single-phase samples for all compounds in the $\mathrm{Ag}_{2} \mathrm{Se}_{-}-\mathrm{Ga}_{2} \mathrm{Se}_{3}$ system by adjusting the $[\mathrm{Ag}] /[\mathrm{Ga}]$ evaporation rates. The Se flux was kept the same in all depositions to always supply a Se overpressure. This was achieved by keeping the Se crucible at $385{ }^{\circ} \mathrm{C}$ during evaporation and verified by weighing the crucible before and after each run. The average Se deposition rate during the run was estimated to be $\sim 50 \AA / \mathrm{s}$, and the Se/metal flux ratio was kept above 8 for all runs. A list of the samples included in this study along with their chemical compositions measured by energy-dispersive X-ray spectroscopy (EDS) is given in Table 2.

Devices with the structure $\mathrm{SLG} / \mathrm{Mo} / \mathrm{AgGaSe}_{2} / \mathrm{CdS} / \mathrm{i}-\mathrm{ZnO} /$ $\mathrm{ZnO}: \mathrm{Al}$ were prepared for two Ag-poor $([\mathrm{Ag}] /[\mathrm{Ga}]<1)$ absorbers (one-stage and three-stage) and one Ag-rich ([Ag]/[Ga] > 1) absorber. A $50 \mathrm{~nm}$ CdS layer was deposited by chemical bath deposition in a solution of $0.01 \mathrm{M}$ cadmium acetate, $0.14 \mathrm{M}$ thiourea, and $1 \mathrm{M}$ ammonia with a process time of $8.25 \mathrm{~min}$ in a $60^{\circ} \mathrm{C}$ water bath. The devices were completed by sputtering an i- $\mathrm{ZnO}(70 \mathrm{~nm}) /$ $\mathrm{ZnO}: \mathrm{Al}(210 \mathrm{~nm})$ window layer stack. Cell definition was performed by mechanical scribing to prepare 16 solar cells with an area of 0.05 $\mathrm{cm}^{2}$ on each sample.

2.2. Device and Material Characterization. Scanning electron microscopy (SEM) and EDS analysis were performed in a Zeiss 1550 system equipped with an Oxford Instruments EDS detector. An acceleration voltage of $10 \mathrm{kV}$ was used for all measurements. Raman spectroscopy was carried out at room temperature in a Renishaw inVia system using lasers with wavelengths of 532,633 , and $785 \mathrm{~nm}$. Power densities in the range of $5-50 \mathrm{~W} / \mathrm{cm}^{2}$ were used. Grazing incidence (GI) and Bragg-Brentano (BB) XRD were performed with a Siemens D5000 system using $\mathrm{Cu} \mathrm{K} \alpha$ radiation. All GIXRD was performed with an incidence angle $\left(d_{\text {inc }}\right)$ of $1^{\circ}$. Reflectance $(R)$ and transmittance $(T)$ measurements on samples deposited on SLG were carried out in a Perkin Elmer Lambda 900 spectrometer with an integrating sphere.

Scanning transmission electron microscopy (STEM) in combination with EDS measurements was performed with a Titan Themis 200 from FEI equipped with a SuperX EDS system. The TEM lamellae of both the Ag-poor one-stage device and the Ag-rich device were prepared with a focused ion beam (FIB) StrataDB235 from FEI. The final polishing was performed at a $5 \mathrm{kV}$ ion acceleration voltage with $\mathrm{XeF}_{2}$ gas assistance.

The three-stage processed device was studied using the high-angle annular dark-field (HAADF) detector in the STEM mode of a $300 \mathrm{kV}$ FEI Titan, equipped with an Oxford X-sight EDS detector. This lamella was prepared in an FEI Versa 3D FIB/scanning electron microscope (FIB/SEM). 
Table 2. Chemical Composition Measured by EDS for the Samples Used for This Study ${ }^{a}$

\begin{tabular}{|c|c|c|c|c|}
\hline & \multicolumn{2}{|c|}{ measured composition } & \multicolumn{2}{|c|}{ formal stoichiometry } \\
\hline & {$[\mathrm{Ag}] /[\mathrm{Ga}]$} & $([\mathrm{Ag}]+[\mathrm{Ga}]) /[\mathrm{Se}]$ & {$[\mathrm{Ag}] /[\mathrm{Ga}]$} & $([\mathrm{Ag}]+[\mathrm{Ga}]) /[\mathrm{Se}]$ \\
\hline \multicolumn{5}{|c|}{ Reference Samples } \\
\hline $\mathrm{Ga}_{2} \mathrm{Se}_{3}$ & & 0.63 & & 0.67 \\
\hline $\mathrm{AgGa}_{5} \mathrm{Se}_{8}$ & 0.15 & 0.65 & 0.2 & 0.75 \\
\hline $\mathrm{Ag}_{9} \mathrm{GaSe}_{6}$ & 10.27 & 1.79 & 9 & 1.67 \\
\hline $\mathrm{Ag}_{2} \mathrm{Se}$ & & 2.27 & & 2 \\
\hline \multicolumn{5}{|c|}{ Devices } \\
\hline $\mathrm{AgGaSe}_{2}$ (Ag-poor 1-stage) & 0.81 & 0.88 & & \\
\hline $\mathrm{AgGaSe}_{2}$ (Ag-poor 3-stage) & 0.81 & 0.92 & & \\
\hline $\mathrm{AgGaSe}_{2}$ (Ag-rich) & 1.16 & 0.93 & & \\
\hline
\end{tabular}

${ }^{a_{T}}$ This includes reference samples deposited for the purpose of characterization of secondary phases and thin films used for devices.

Completed solar cells were characterized by current-voltage (JV) analysis at $25{ }^{\circ} \mathrm{C}$ under illumination using an $\mathrm{ELH}$ lamp. The illumination intensity was calibrated to be equivalent to one sun with a reference $\mathrm{Si}$ diode. External quantum efficiency (EQE) measurements were performed on a home-built setup calibrated with $\mathrm{Si}$ and InGaAs references.

\section{RESULTS AND DISCUSSION}

3.1. Identification of Phases in the Pseudobinary $\mathrm{Ag}_{2} \mathrm{Ga}-\mathrm{Ga}_{2} \mathrm{Se}_{3}$ System. To be able to identify secondary phases in $\mathrm{AgGaSe}_{2}$ thin-film absorbers, a set of reference materials was prepared. This also serves the purpose to investigate which polymorphs are produced under our coevaporation conditions. A second aim is to obtain Raman spectra of phases that have not been reported in the literature and enable measurement of Raman spectra under identical conditions for all samples. The XRD patterns of all samples are compared to literature patterns in the Supporting Information (Figures S1-S5). The space groups of the matched phases are listed in Table 3. All diffractograms agree well with the

Table 3. Band Gaps Estimated from Spectrophotometry and Space Groups Determined from XRD Analysis of Reference Samples $^{a}$

\begin{tabular}{lcl}
\multicolumn{1}{c}{ phase } & estimated band gap [eV] & \multicolumn{1}{c}{ space group } \\
$\mathrm{Ga}_{2} \mathrm{Se}_{3}$ & 2.21 & $C \mathrm{c}(9)^{30}$ \\
$\mathrm{AgGa}_{5} \mathrm{Se}_{8}$ & 2.11 & $\overline{4} 2 m(111)^{22}$ \\
$\mathrm{AgGaSe}_{2}$ & 1.78 & $\overline{I 4} 2 d(122)^{35}$ \\
$\mathrm{Ag}_{9} \mathrm{GaSe}_{6}$ & 0.6 & $\overline{4} 3 m(216)^{39}$ \\
$\mathrm{Ag}_{2} \mathrm{Se}$ & & $P 2_{1} 2_{1} 2_{1}(19)^{40}$
\end{tabular}

${ }^{a}$ The measurement data are available in the Supporting Information. The numbers in parentheses indicate the space group number.

literature data except for the $\mathrm{AgGa}_{5} \mathrm{Se}_{8}$ sample, where only one study is available. ${ }^{22}$ Instead, $\mathrm{AgGa}_{5} \mathrm{Se}_{8}$ matches the XRD pattern simulated based on the reported crystal structure of $\mathrm{AgIn}_{5} \mathrm{Se}_{8}{ }^{28}$ with $5 \%$ smaller lattice constants (see Figure S5), which is consistent with the difference in lattice constants of the corresponding chalcopyrite compounds. Most reference samples appear to be single phase based on XRD. The only exception is the $\mathrm{AgGa}_{5} \mathrm{Se}_{8}$ sample, which contains small $\mathrm{AgGaSe}_{2}$ crystals on the film surface visible by optical microscopy (not shown). It is surprising that particles with the chalcopyrite structure were present in the sample with the integral composition of $[\mathrm{Ag}] /[\mathrm{Ga}]=0.15$, which is lower than the expected $[\mathrm{Ag}] /[\mathrm{Ga}]=0.2$ in $\mathrm{AgGa}_{5} \mathrm{Se}_{8}$. Either this is an indication that the EDS measurement is not accurate or that the OVC phase is in fact even more Ag-poor, like $\mathrm{AgGa}_{7} \mathrm{Se}_{11}$ proposed by Mikkelsen. ${ }^{20}$ The OVC phase will be discussed in more detail below. Table 3 also includes estimated band gaps of the reference materials based on spectrophotometry. The extracted band gaps are in good agreement with the values reported in the literature (see Table 1). The absorption coefficients extracted from spectrophotometry are available in Figure S6.

Figure 1 shows the XRD patterns of all the reference samples. It is noticed that the separation of the main peaks is

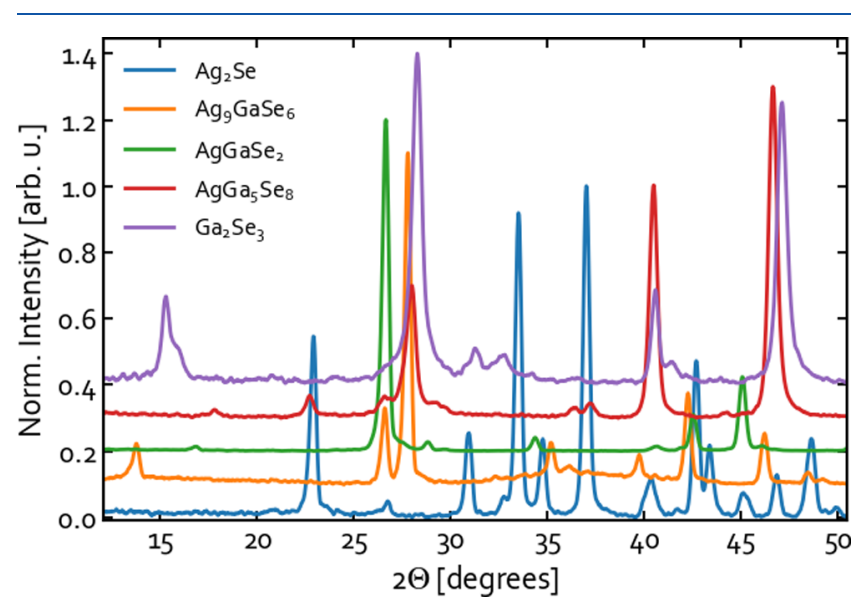

Figure 1. XRD of samples representing all phases in the $\mathrm{Ag}_{2} \mathrm{Se}-$ $\mathrm{Ga}_{2} \mathrm{Se}_{3}$ pseudobinary system. All phases produce unique patterns.

sufficient to recognize the phases, and each phase has a unique pattern. This observation makes it possible to probe the presence of any secondary phase by XRD provided sufficient volume fraction of it is present in the sample.

Raman spectroscopy has been successfully applied to distinguish secondary phases in the $\mathrm{Cu}_{2} \mathrm{ZnSeS}_{4}$ system (e.g., in ref 48) and for identification of OVCs in CIGS(e) (e.g., in ref 49). Since Raman is a fast measurement technique that allows detection of spatial variations on the micrometer scale, it might be useful for distinguishing the secondary phases in the $\mathrm{Ag}_{2} \mathrm{Se}_{-}-\mathrm{Ga}_{2} \mathrm{Se}_{3}$ system as well. The Raman spectra of the reference samples measured with 532, 633, and $785 \mathrm{~nm}$ excitation wavelengths are included in the Supporting Information (see Figures S7-S9). By probing the samples with different laser wavelengths, excitation powers, and exposure times, it was realized that some samples are highly sensitive to laser beam exposure. It has previously been observed that silver chalcogenides can react with air during 

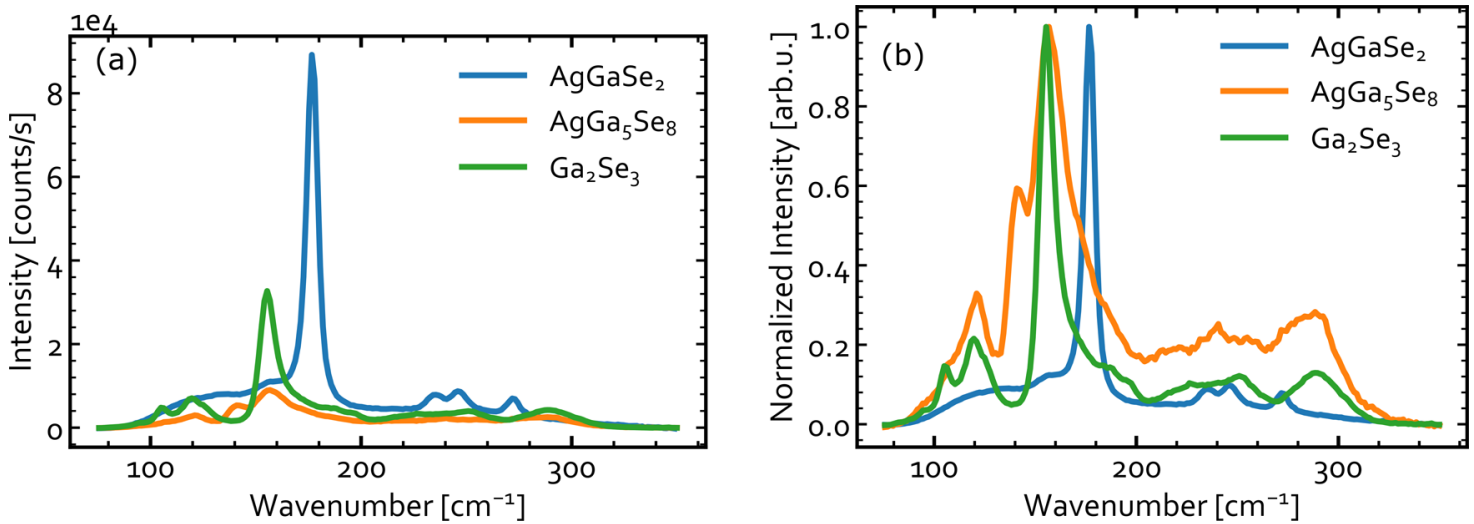

Figure 2. (a) As-measured and (b) normalized Raman spectra of the reference samples measured under identical conditions with $785 \mathrm{~nm}$ excitation. The $\mathrm{AgGaSe}_{2}$ sample is the Ag-poor one-stage absorber shown in Table 2.

light exposure. $\mathrm{Ag}_{2} \mathrm{Te}^{50,51}$ and $\mathrm{Ag}_{2} \mathrm{Se}^{52}$ for example, tend to oxidize in air during Raman measurements. Photoinduced redox reactions have likewise been demonstrated in $\mathrm{Ga}_{2} \mathrm{Se}_{3} .{ }^{53}$ Since these effects were observed even when using low laser power and short laser exposure, it was difficult to obtain highquality Raman spectra of some samples. These effects appeared to be especially prominent when using a $532 \mathrm{~nm}$ laser, while the samples were more stable under $785 \mathrm{~nm}$ illumination. More details regarding the challenges of Raman analysis are available in the Supporting Information (SI).

Figure 2a shows the Raman spectra of the reference samples measured under identical conditions with $785 \mathrm{~nm}$ excitation. $\mathrm{Ag}_{2} \mathrm{Se}$ and $\mathrm{Ag}_{9} \mathrm{GaSe}_{6}$ were not included since no Raman-active vibrations that could be ascribed to these phases were detected in the samples. It is currently unclear why the $\mathrm{Ag}_{2} \mathrm{Se}$ sample did not appear to be Raman-active, contrary to the earlier studies presented in the literature. ${ }^{42,43}$ Figure $2 \mathrm{a}$ shows that the samples with the strongest Raman response under these measurement conditions are $\mathrm{AgGaSe}_{2}$ and $\mathrm{Ga}_{2} \mathrm{Se}_{3}$. Therefore, if these are present in a phase mixture, they are expected to provide a dominant signal. The $\mathrm{AgGa}_{5} \mathrm{Se}_{8}$ phase also gives distinct (although relatively weak) Raman peaks. It is thus expected that this phase could be detected in a mixture with $\mathrm{AgGaSe}_{2}$ given a large enough fraction of the probed volume consists of the $\mathrm{AgGa}_{5} \mathrm{Se}_{8}$ phase. Figure $2 \mathrm{~b}$ shows the normalized Raman spectra for better comparison. In the $\mathrm{AgGaSe}_{2}$ sample, peaks were detected at 178, 234, 247, and $273 \mathrm{~cm}^{-1}$, with the bold number indicating the strongest peak. These vibrations are in general agreement with the Raman spectra previously published for $\mathrm{AgGaSe} e_{2}{ }^{36,37}$ In the $\mathrm{Ga}_{2} \mathrm{Se}_{3}$ sample, peaks were observed at 107, 120, 155, 195, 252, and $293 \mathrm{~cm}^{-1}$. These modes are also in good agreement with previously published spectra for $\mathrm{Ga}_{2} \mathrm{Se}_{3} .{ }^{32,33}$ For the $\mathrm{AgGa}_{5} \mathrm{Se}_{8}$ sample, Raman peaks were detected at 120, 141, 156, 240, 255, and $288 \mathrm{~cm}^{-1}$. It is noticed that the signals from $\mathrm{AgGa}_{5} \mathrm{Se}_{8}$ and $\mathrm{Ga}_{2} \mathrm{Se}_{3}$ are similar. The major differences are that $\mathrm{AgGa}_{5} \mathrm{Se}_{8}$ exhibits significantly broader main peak and one extra vibration at $142 \mathrm{~cm}^{-1}$. This unique peak was, however, only observed using the 785 and $633 \mathrm{~nm}$ laser wavelengths but was not the $532 \mathrm{~nm}$ laser (see the Supporting Information). The resemblance of these Raman spectra is likely a result of the similarities in chemical composition and nature of vacancy ordering in the zinc-blende-derived crystal structure. The 155 $\mathrm{cm}^{-1}$ mode in $\mathrm{Ga}_{2} \mathrm{Se}_{3}$ was previously shown to have $\mathrm{A} 1$ symmetry. ${ }^{32}$ By extension, the $156 \mathrm{~cm}^{-1}$ mode of $\mathrm{AgGa}_{5} \mathrm{Se}_{8}$ is likely to be the A1 mode as well. The Raman spectrum of
$\mathrm{AgGa}_{5} \mathrm{Se}_{8}$ has not been reported in the literature, but $\mathrm{CuGa}_{5} \mathrm{Se}_{8}$ has been studied in detail. ${ }^{24,54}$ The Al mode in these materials results from the motion of the Se atoms while the cations remain at rest. It has been argued that the vacancies present in the OVC reduce the stretching forces involved in the vibration and therefore lowers the Al frequency compared to the chalcopyrite. According to the model of Neumann, ${ }^{55}$ the frequency of the $\mathrm{A} 1$ mode can be described by $\nu \approx\left(k / M_{\mathrm{Se}}\right)^{1 / 2}$, where $M_{\mathrm{Se}}$ is the mass of selenium and $k$ is the cation-Se bond-stretching force constant. Since one vacancy exists for every four $\mathrm{Se}$ atoms in $\mathrm{CuGa}_{5} \mathrm{Se}_{8}$, it was argued that $k$ is reduced by $25 \%$ relative to the chalcopyrite $\mathrm{CuGaSe}_{2}$. As a result, it is estimated that the frequency of the A1 mode in $\mathrm{CuGa}_{5} \mathrm{Se}_{8}$ is $\nu_{1-5-8} \approx 0.87 \nu_{\mathrm{CH}}$, where $\nu_{\mathrm{CH}}$ is the frequency of the Al mode in $\mathrm{CuGaSe}_{2} \cdot{ }^{24,54}$ The A1 mode of $\mathrm{CuGa}_{5} \mathrm{Se}_{8}$ was observed at $158-161 \mathrm{~cm}^{-1}$ depending on the growth method, ${ }^{24}$ and the A1 mode in $\mathrm{CuGaSe}_{2}$ is observed at 184 $\mathrm{cm}^{-1}$, which is in good agreement with the model. The A1 mode measured in $\mathrm{AgGaSe}_{2}$ samples in this study appears at $178 \mathrm{~cm}^{-1}$, while the $\mathrm{A} 1$ mode in the $\mathrm{AgGa}_{5} \mathrm{Se}_{8}$ sample is observed at $156 \mathrm{~cm}^{-1}$. This amounts to a reduction of the A1 frequency in the OVC by a factor of $\sim 0.87$ when comparing to the chalcopyrite in the Ag-Ga-Se system as well.

Based on the presented measurements, it is concluded that Raman spectroscopy is unsuited to identify $\mathrm{Ag}_{9} \mathrm{GaSe}_{6}$ and $\mathrm{Ag}_{2} \mathrm{Se}$ secondary phases, while $\mathrm{AgGaSe}_{2}, \mathrm{AgGa}_{5} \mathrm{Se}_{8}$, and $\mathrm{Ga}_{2} \mathrm{Se}_{3}$ can be detected. With the established reference Raman and XRD signatures of individual phases in the Ag$\mathrm{Ga}-\mathrm{Se}$ system, we can now proceed to analyze $\mathrm{AgGaSe}_{2}$ absorbers. Two types of samples are recognized here: Ag-rich (with $\mathrm{Ag}_{9} \mathrm{GaSe}_{6}$ ) and $\mathrm{Ag}$-poor (with $\mathrm{AgGa}_{5} \mathrm{Se}_{8}$ ). These two cases are separated into the respective subsections below.

3.2. Impact of the $\mathrm{Ag}_{9} \mathrm{GaSe}_{6}$ Secondary Phase on Device Behavior. Figure 3 shows the GIXRD pattern of the sample labeled $\mathrm{AgGaSe}_{2}$ (Ag-rich) in Table 2. The integral $[\mathrm{Ag}] /[\mathrm{Ga}]$ ratio for this sample was determined to be 1.16 by EDS. The XRD pattern in Figure 3 indicates that this sample contains $\mathrm{Ag}_{9} \mathrm{GaSe}_{6}$ along with the chalcopyrite $\mathrm{AgGaSe}_{2}$. The presence of the $\mathrm{Ag}_{9} \mathrm{GaSe}_{6}$ phase in the Ag-rich device makes the Ag-based chalcopyrites different from their $\mathrm{Cu}$-based counterparts, where $\mathrm{Cu}_{\mathrm{x}} \mathrm{Se}$ is formed when grown under $\mathrm{Cu}$ rich conditions. Since $\mathrm{Cu}_{x} \mathrm{Se}$ is conductive, the presence of these inclusions causes shunting of solar cells. $\mathrm{Ag}_{2} \mathrm{Se}$ is also highly conductive (see the Supporting Information), so shunting is expected if this phase would form. In the $\mathrm{Ag}_{2} \mathrm{Se}-$ $\mathrm{Ga}_{2} \mathrm{Se}_{3}$ system, however, $\mathrm{Ag}_{2} \mathrm{Se}$ only start forming for [Ag]/ 


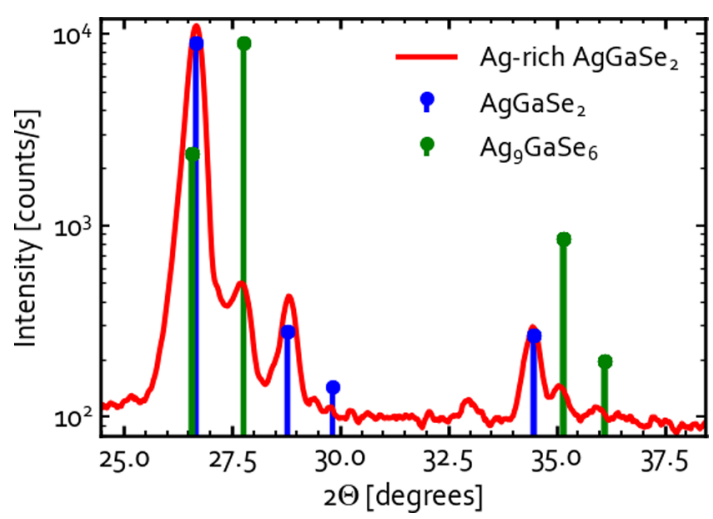

Figure 3. GIXRD $\left(d_{\text {inc }}=1^{\circ}\right)$ pattern of the Ag-rich AgGaSe 2 absorber (integral $[\mathrm{Ag}] /[\mathrm{Ga}]=1.16$ by EDS) containing inclusions of the $\mathrm{Ag}_{9} \mathrm{GaSe}_{6}$ phase. The reflections related to $\mathrm{AgGaSe}_{2}$ and $\mathrm{Ag}_{9} \mathrm{GaSe}_{6}$ are indicated. Details regarding the reference patterns are available in the Supporting Information.

[Ga] > 9, while $\mathrm{Ag}_{9} \mathrm{GaSe}_{6}$ coexists with the chalcopyrite phase in the range $1<[\mathrm{Ag}] /[\mathrm{Ga}]<9 .^{20}$ Since the situation is different from the widely studied CIGS(e) system, it is interesting to investigate how the presence of $\mathrm{Ag}_{9} \mathrm{GaSe}_{6}$ affects solar cell performance. Figure 4 shows the JV curve of the Ag-

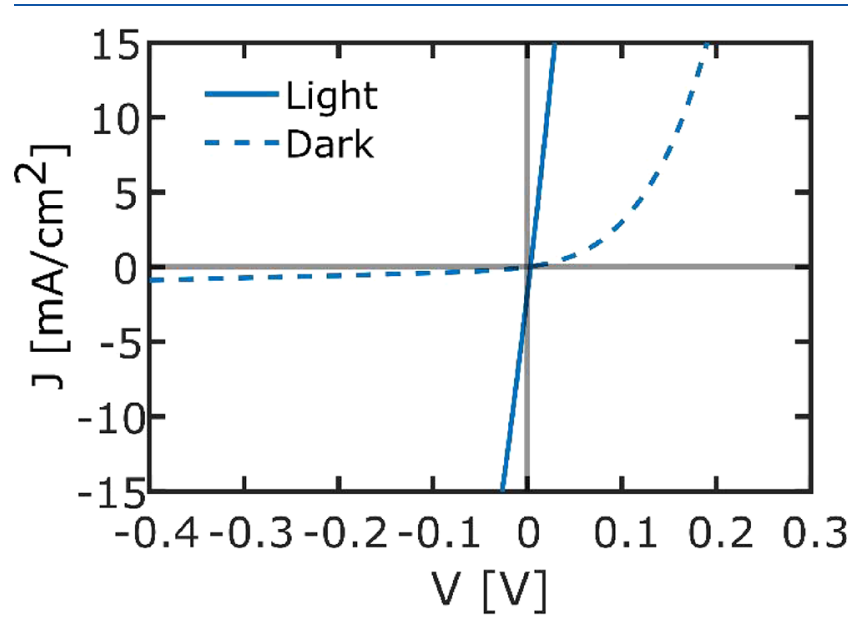

Figure 4. JV curve of Ag-rich $\mathrm{AgGaSe}_{2}$ solar cell containing inclusions of $\mathrm{Ag}_{9} \mathrm{GaSe}_{6}$.

rich device. The JV curve measured in the dark indicates that the device behaves like a diode. It has a very high dark saturation current density, resulting in a very low turn-on voltage. This is indicative of very strong recombination in the device. Recombination could be facilitated by the presence of $\mathrm{Ag}_{9} \mathrm{GaSe}_{6}$ that has a band gap of about $0.6 \mathrm{eV}$ (see Table 3). When the device is illuminated, the JV curve evolves into a straight line, indicating complete shunting of the solar cell. Such an impact of illumination is unusual and somewhat surprising. One explanation for it could be photoconductivity of $\mathrm{Ag}_{9} \mathrm{GaSe}_{6}$. Indeed, it was determined that this phase is photoactive as its apparent resistivity decreases by $\sim 30 \%$ under illumination (see Figure S14). The material still remained highly resistive (around $4 \Omega \cdot \mathrm{m}$ ) under illumination, hence it is unlikely that the photoactivity of $\mathrm{Ag}_{9} \mathrm{GaSe}_{6}$ fully explains the observed JV behavior. It should be noted that the sheet resistance measurement probes the lateral resistivity, where grain boundaries can play a role. The vertical resistivity may, however, be lower due to fewer grain boundaries. It is also important to point out that the resistivity of the $\mathrm{Ag}_{9} \mathrm{GaSe}_{6}$ sample in this study was 4 orders of magnitude higher than that reported for the material grown in sealed quartz tubes, which behaved as degenerated semiconductors ${ }^{56,57}$ (see more details in the Supporting Information).

The distribution of the $\mathrm{Ag}_{9} \mathrm{GaSe}_{6}$ phase in the thin film was studied in order to verify if it could be the origin of shunting. TEM and EDS imaging of this sample are shown in Figure 5. The darker grains in the TEM represent material with a higher density. An EDS line scan across the border between the lighter and darker regions allows identification of the phases (Figure $5 b$ ). In the lighter material, a composition of Ag: 19\%, Ga: $25 \%$, and Se: $56 \%$ was measured. Still, the light grains were ascribed to stoichiometric $\mathrm{AgGaSe}{ }_{2}$, which must be prevailing in the absorber grown under Ag-rich conditions. One can notice that measured and nominal composition of the chalcopyrite phase diverges, with EDS underestimating $\mathrm{Ag}$ and overestimating Se contents by about 6 at \%. There are several possible reasons for this discrepancy. Either it relates to the EDS quantification errors or due to compositional changes induced by the sample preparation (additional Ga could be introduced during milling of lamella with Ga-ion beam). Moreover, Ag could be lost during preparation and measurement. Indeed, it was observed that Ag-rich particles formed rapidly on the lamella surface during FIB polishing (see Figure S19 in the Supporting Information) and even under exposure to the electron beam in TEM. In the dark area, a composition of $\mathrm{Ag}$ : 43\%, Ga: $8 \%$, and Se: $49 \%$ was determined. In stoichiometric $\mathrm{Ag}_{9} \mathrm{GaSe}_{6}$, one should ideally measure the composition of Ag: $56 \%$, Ga: $6 \%$, and Se: $38 \%$. Based on the EDS results, it is fair to assume that the dark regions in the TEM image are $\mathrm{Ag}_{9} \mathrm{GaSe}_{6}$ since this phase was clearly identified by XRD. Again, it seems that the measured Ga content agrees with the expectation, while Se concentration is overestimated at the expense of Ag. In this case, the error in $\mathrm{Ag}$ and Se is of the order of $11-13$ at \%. The systematic character of the error in different phases rather points to an EDS quantification issue. At the same time, it has to be kept in mind that the area used for the quantification could contain a mixture or overlay of $\mathrm{Ag}_{9} \mathrm{GaSe}_{6}$ and $\mathrm{AgGaSe}_{2}$. While most of the $\mathrm{Ag}_{9} \mathrm{GaSe}_{6}$ phase is located at the back contact, one grain extends through the entire film thickness. In the Supporting Information, an additional image is included, where it can be seen that $\mathrm{Ag}_{9} \mathrm{GaSe}_{6}$ can also form on the surface of the film. The fact that the $\mathrm{Ag}_{9} \mathrm{GaSe}_{6}$ locally connects the front and back contact could be the reason for the shunting observed in the JV measurements, although some questions remain regarding the shunting behavior.

3.3. Impact of $\mathrm{AgGa}_{5} \mathrm{Se}_{8}$ Inclusions on Device Behavior. It has been determined that the presence of $\mathrm{Ag}_{9} \mathrm{GaSe}_{6}$ in the absorber layer is detrimental to solar cell performance. To avoid the formation of this phase, the material can instead be grown slightly Ag-poor. However, OVC inclusions are already observed for the material with $[\mathrm{Ag}] /[\mathrm{Ga}]<0.96 .^{20}$ The increased tendency of OVC formation in Ag-alloyed CIGS(e) with high Ga and Ag contents was explored in a recent publication from our group. ${ }^{58}$ In this section, the picture is nuanced by studying the ternary $\mathrm{Cu}$ - and In-free alternative and by comparison of absorbers prepared by a one- and three-stage co-evaporation process. In the one-stage process, the evaporation rate of all elements is kept constant throughout the deposition. In the 

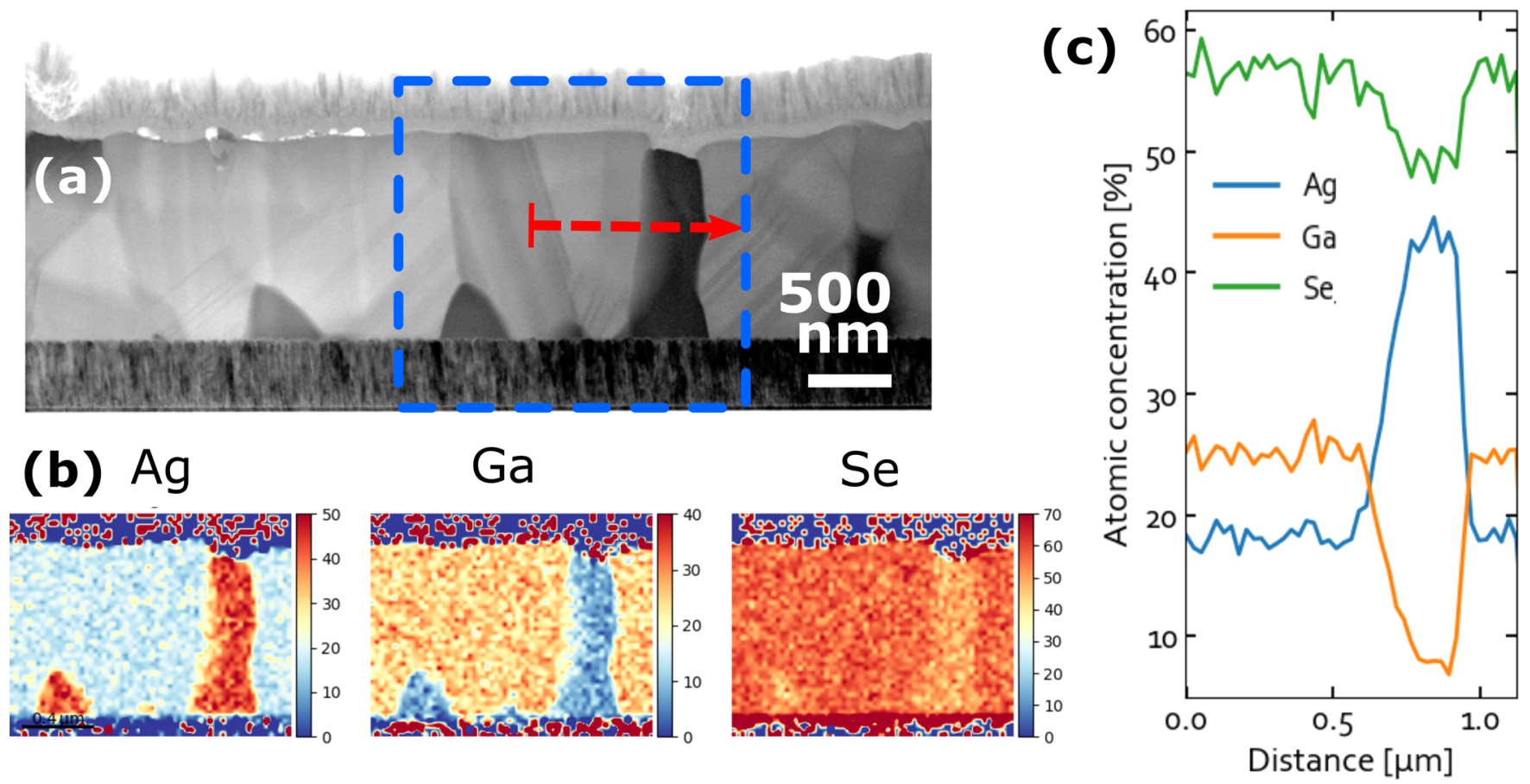

Figure 5. (a) TEM micrograph of the Ag-rich AgGaSe ${ }_{2}$ sample. (b) STEM-EDS elemental maps in the region indicated with the blue dashed box. (c) STEM-EDS line scan along the red dashed arrow.
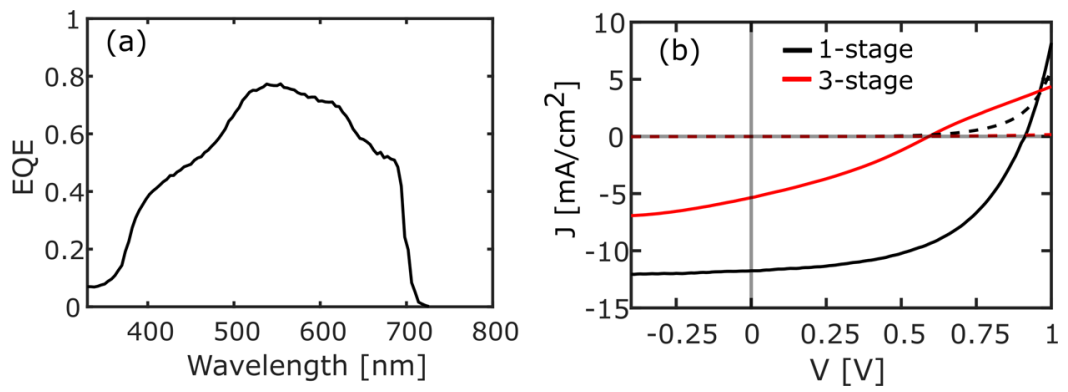

Figure 6. (a) EQE of Ag-poor $\mathrm{AgGaSe}_{2}$ grown with one-stage co-evaporation. The band gap is estimated to be $1.76 \mathrm{eV}$ based on the maximum of the derivative. (b) Comparison of current-voltage curves of Ag-poor solar cells produced with one- and three-stage processes. The solid and dashed curves are measured under 1 sun illumination and in the dark, respectively.

three-stage process, the first stage is Ag-poor, the second stage is Ag-rich (reaching integral composition of $[\mathrm{Ag}] /[\mathrm{Ga}] \sim 1.2$ at the end of the second stage), and the final third stage is again Ag-poor. The three-stage process is commonly used to produce a high-efficiency CIGS(e) absorber material. ${ }^{47}$ The samples compared here were designed to have very similar compositions with integral $[\mathrm{Ag}] /[\mathrm{Ga}]=0.81$, leading to segregation of $\mathrm{AgGa}_{5} \mathrm{Se}_{8}$ OVC alongside $\mathrm{AgGaSe}_{2}$ for both samples (see Figure S16 in the Supporting Information). The differences in material properties and device performance are therefore primarily related to the type of the deposition process used.

Figure 6a shows the EQE of the Ag-poor sample deposited with a one-stage process. The band gap value extracted from the EQE using the maximum of the derivative is $1.76 \mathrm{eV}$. This is slightly lower than $1.78 \mathrm{eV}$ estimated from photoluminescence and spectrophotometry (Figure S6 and S15 in the Supporting Information).

Figure $6 \mathrm{~b}$ shows the JV curves of the two Ag-poor devices and Table 4 summarizes the extracted parameters $\left(V_{\mathrm{OC}}\right.$ : opencircuit voltage, $J_{\mathrm{SC}}$ : short-circuit current density, and FF: fill
Table 4. Device Parameters of the Best Cells Extracted from JV Measurements of Ag-Poor Devices Produced with Oneand Three-Stage Processes ${ }^{a}$

$\begin{array}{llclc} & V_{\mathrm{OC}}[\mathrm{mV}] & J_{\mathrm{SC}}\left[\mathrm{mA} / \mathrm{cm}^{2}\right] & F F[\%] & \text { efficiency [\%] } \\ \text { 1-stage } & 911(833) & 12.2(11.7) & 53(52) & 5.8(5.1) \\ \text { 3-stage } & 592(590) & 5.3(2.1) & 32(34) & 1.0(0.4)\end{array}$

${ }^{a_{T}}$ The values in parentheses are the average of 16 cells.

factor). It is clear that the sample deposited with the threestage process has a severe kink, while the one-stage processed device does not. The kink and low $J_{S C}$ of the three-stage absorber can relate to a blocking barrier for carrier transport. Based on the analysis of the reference samples (see the Supporting Information), $\mathrm{AgGa}_{5} \mathrm{Se}_{8}\left(E_{\mathrm{g}}=2.11 \mathrm{eV}\right)$ has a significantly wider band gap than $\mathrm{AgGaSe}_{2}\left(E_{\mathrm{g}}=1.78 \mathrm{eV}\right)$. First-principles calculations based on the density functional theory found that the valance band offset between $\mathrm{AgGaSe}_{2}$ and $\mathrm{AgGa}_{5} \mathrm{Se}_{8}$ is expected to be $0.42 \mathrm{eV} .^{59}$ The OVC therefore has the potential to block the hole transport at the back contact, but whether this happens depends on the spatial 

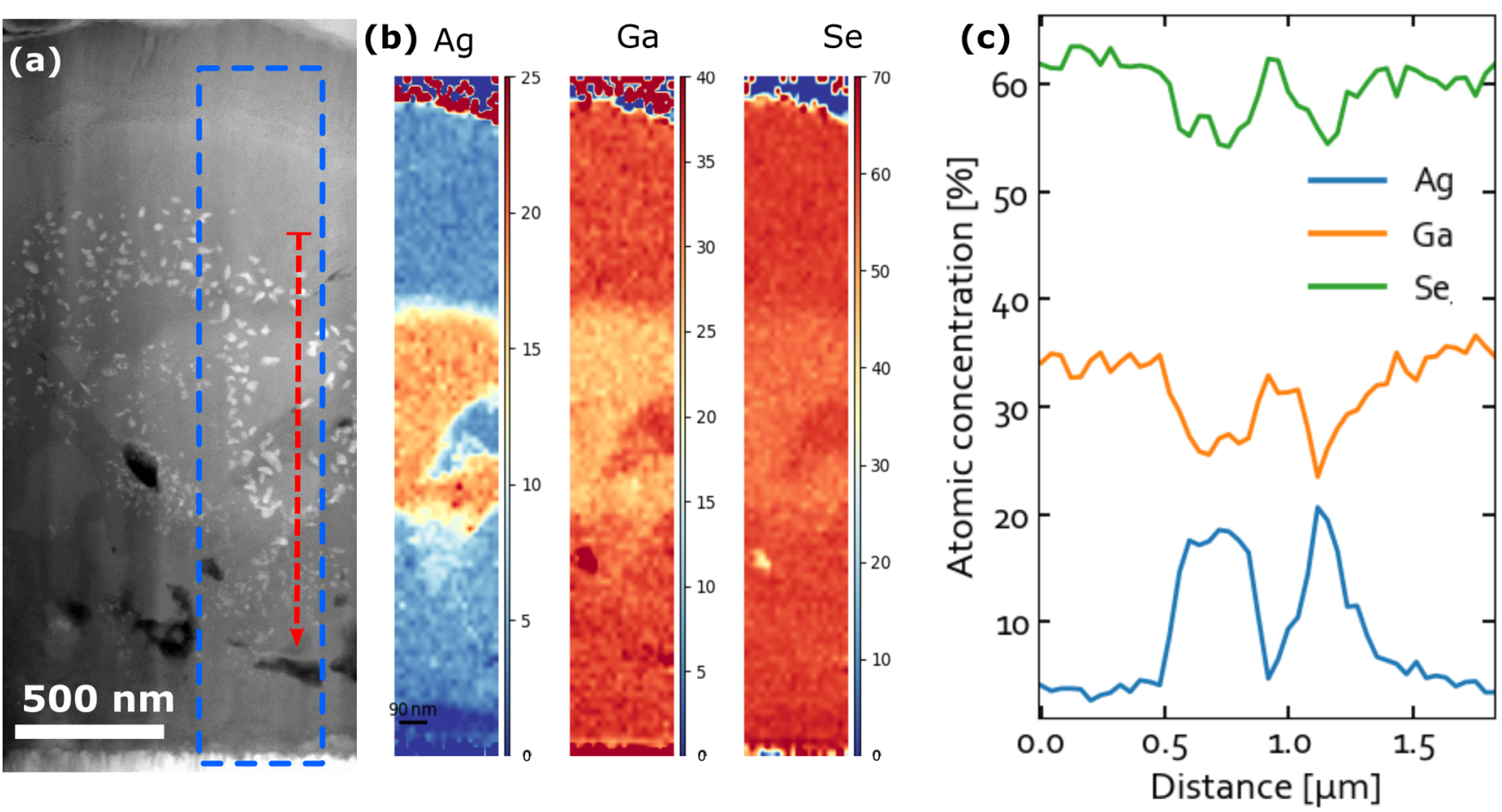

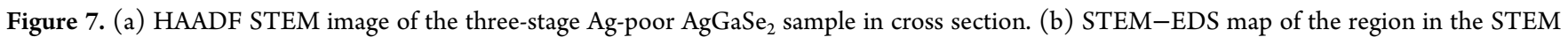
image encompassed by a blue dashed box. (c) EDS line profiles extracted from (b) along the red dashed arrow in (a).

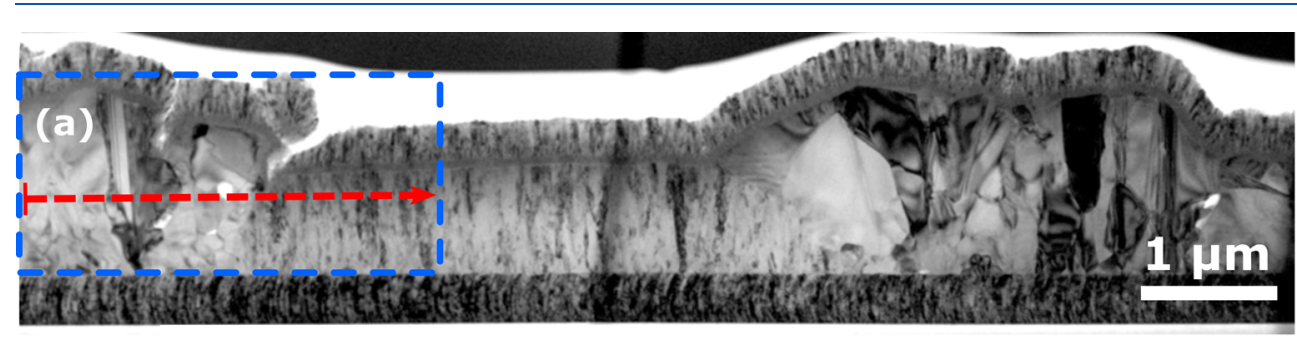

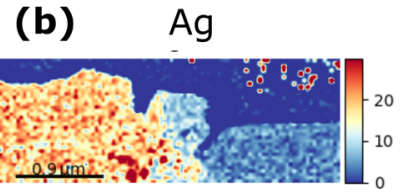

$\mathrm{Se}$

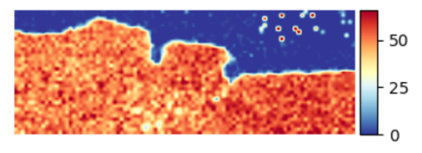

$\mathrm{Ga}$

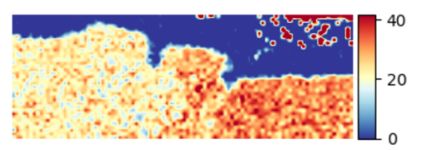

$\mathrm{Zn}$

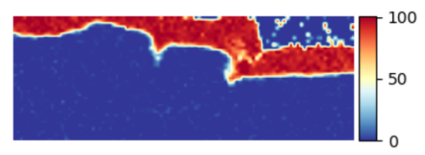

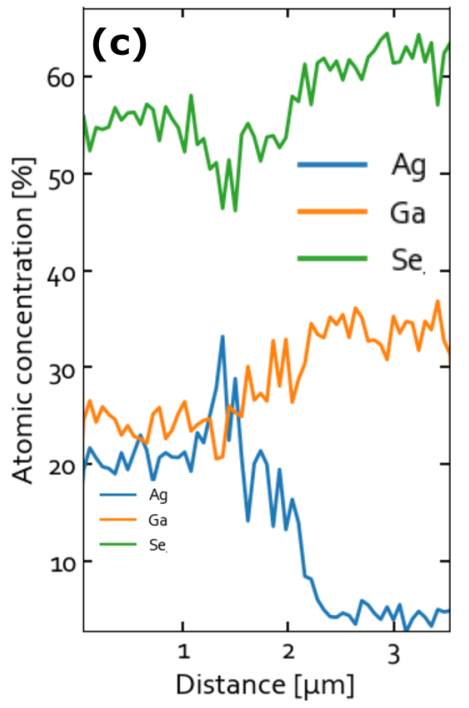

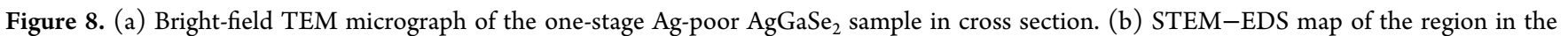
TEM image encompassed by a blue dashed box. (c) STEM-EDS line scan extracted from the map (b) along the red dashed arrow crossing the boundary between the $\mathrm{AgGaSe}$ and OVC grains. Note the presence of $\mathrm{Ag}$ precipitates triggered by the EDS map acquisition. In order to limit the damages, the electron beam current and acquisition time were kept low, leading to a slightly noisier dataset.

distribution of the secondary phase. In principle, a continuous layer of OVCs could impede current flow, whereas the formation of dispersed OVC regions would rather reduce active volume for light absorption and/or carrier extraction, thereby lowering $J_{\mathrm{SC}}$ but causing no deflection in the JV curve. The OVC distribution within the absorber films was analyzed with STEM-EDS, as shown in Figures 7 and 8.

Figure 7a shows a cross-sectional STEM image of the Agpoor device deposited with the three-stage process. The different phases exhibit a slight contrast in the HAADF image.
In the Supporting Information, an additional SEM crosssectional micrograph is shown to illustrate the contrast in a larger cross section (see Figure S19). The small bright particles seen on the surface relate to Ag-rich precipitates that are formed during the TEM measurement. These are not inherent to the as-deposited material, as shown in Figure S19 in the Supporting Information. The elemental maps shown in Figure $7 \mathrm{~b}$ demonstrate that the layer in the middle of the film has a higher Ag concentration and a lower Ga concentration than the layers at the front surface and back contact. The line scan 
in Figure $7 \mathrm{c}$ shows the change in chemical composition across the grain boundaries. In the central region, a composition of Ag: $19 \%$, Ga: $26 \%$, and Se: $55 \%$ is found, which nearly matches the composition of the chalcopyrite phase in the Ag-rich sample (see Figure 5). The difference in composition of the bulk chalcopyrite phase in equilibrium with $\mathrm{AgGa}_{5} \mathrm{Se}_{8}$ (Agpoor growth) and $\mathrm{Ag}_{9} \mathrm{GaSe}_{6}$ (Ag-rich growth) can be used to estimate the width of the single-phase region for the chalcopyrite compound. The error in EDS quantification in not particularly important here because it affects the $\mathrm{AgGaSe} \mathrm{S}_{2}$ phase equally in both samples. The difference in $[\mathrm{Ag}] /[\mathrm{Ga}]$ is found to be about $3-4 \%$, in good agreement with the phase diagram published by Mikkelsen. ${ }^{20}$ This result is a direct confirmation of the very low tolerance of $\mathrm{AgGaSe}_{2}$ to offstoichiometry.

The composition of the layers located at the top and near the back contact is about: Ag: 4\%, Ga: 35\%, and Se: 61\%, which is close to $\mathrm{AgGa}_{7} \mathrm{Se}_{11}$ (Ag: 5\%, Ga: $37 \%$, and Se: $58 \%$ ). If we assume that $\mathrm{Se}$ content is overestimated at the expense of $\mathrm{Ag}$ by a few percent, the actual values would be close to the nominal composition of the $\mathrm{AgGa}_{5} \mathrm{Se}_{8}$ compound: $\mathrm{Ag}$ : 7\%, Ga: $36 \%$, and Se: $57 \%$. These results therefore show that it is either $\mathrm{AgGa}_{5} \mathrm{Se}_{8}$ or $\mathrm{AgGa}_{7} \mathrm{Se}_{11}$, which constitute the stable OVC phase that forms under Ag-deficit growth conditions rather than $\mathrm{AgGa}_{3} \mathrm{Se}_{5}$ (Ag: 11\%, Ga: 33\%, and Se: 56\%). Intriguingly, the OVC with 1:3:5 composition is uniquely absent in the Ag$\mathrm{Ga}-\mathrm{Se}$ system, while present in the $\mathrm{Ag}-\mathrm{In}-\mathrm{Se}, \mathrm{Cu}-\mathrm{In}-\mathrm{Se}$, and $\mathrm{Cu}-\mathrm{Ga}-\mathrm{Se}$ systems. It is noticed that a surprisingly large volume of the lamella consists of the OVC phase given the integral $[\mathrm{Ag}] /[\mathrm{Ga}]=0.81$. In the Supporting Information, it is discussed that $\mathrm{Ag}$ could be lost from the sample during preparation resulting in decomposition of $\mathrm{AgGaSe}_{2}$ and consequent growth of the OVC regions.

The TEM analysis leads us to conclude that the three-stage processed device consists of a layer of chalcopyrite material sandwiched between two OVC layers. The presence of wide band gap OVC as quasi-continuous layers at both interfaces explains why the device processed with the three-stage process exhibits a current-blocking behavior.

Unlike the three-stage processed device, the one-stage device was not blocking (see Figure 6). In an attempt to explain the different device behavior, the microstructure of the one-stage device was likewise investigated by TEM. Figure 8 shows the STEM-EDS analysis of the completed device. The compositional maps in Figure $8 \mathrm{~b}$ show a magnified view of an area containing two regions with very different compositions. In the left region, the measured composition is Ag: $20 \%$, Ga: $25 \%$, and Se: $55 \%$. Taking into account the systematic error in $\mathrm{Ag}$ and $\mathrm{Se}$ contents, this composition is interpreted as nearstoichiometric or slightly Ag-poor $\mathrm{AgGaSe}_{2}$. A spike in the $\mathrm{Ag}$ content in the line scan relates to a small Ag-rich particle formed on the lamella during the preparation or TEM analysis. The right part of the elemental map has a composition of around Ag: $5 \%$, Ga: $35 \%$, and Se: $60 \%$. This is very similar to that of the OVC in the three-stage sample. It is therefore deduced that the region in the center of the lamella is the $\mathrm{AgGa}_{5} \mathrm{Se}_{8}$ or $\mathrm{AgGa}_{7} \mathrm{Se}_{11}$ phase. It is noted that the grains are much smaller in the OVC region than in the surrounding chalcopyrite and the thickness of the film is locally reduced. A few additional SEM and TEM images are provided in the Supporting Information. The conclusion of the microstructural investigation is that the OVC grains are distributed very differently in the one- and three-stage processed samples. In the one-stage sample, the OVC patches are dispersed laterally and extended through the entire film thickness, whereas quasicontinuous OVC layers at the front and back surfaces are found in the three-stage sample. The fact that the OVC does not cover the entire surface in the one-stage sample explains why the device is not blocked. When OVC patches are distributed in this fashion, they appear to be less detrimental. It may, however, be preferred to completely eliminate OVCs, which would likely require hitting nearly perfect chalcopyrite stoichiometry within the range of $0.96<[\mathrm{Ag}] /[\mathrm{Ga}]<1$. This is, however, not trivial to do consistently with thermal evaporation due to the difficulty to control the elemental flux with the required precision. Nonetheless, even without the extensive efforts, the obtained conversion efficiency of $5.8 \%$ is the highest reported for any $\mathrm{AgGaSe}_{2}$ solar cells to date. This is not particularly impressive in comparison with similar CIGS(e)-based materials, leaving a lot of room for improvement. The fact that better devices have not yet been reported is partly due to the limited number of studies on $\mathrm{AgGaSe}_{2}$ with solar cell applications in mind. To enhance the performance of $\mathrm{AgGaSe}_{2}$ devices, it might be beneficial to attempt widening the single-phase region. This could, for example, be done by alloying with $\mathrm{In}$ and $\mathrm{Cu}$, as discussed by Keller et al. ${ }^{58}$ It has been suggested that $\mathrm{Na}$ widens the single-phase region of chalcopyrite $\mathrm{CuInSe} \mathrm{S}_{2}{ }^{60}$ Other studies instead report that alkali elements may promote the formation of OVCs. ${ }^{58,61,62}$ This idea is supported by the finding that deposition of $\mathrm{AgGaSe}_{2}$ directly on glass resulted in the formation of a larger amount of OVCs than in the films deposited on Mo-coated SLG (see Figure S17 and accompanying discussion in the Supporting Information). The role of alkalis on the formation of OVCs and the width of the single-phase region therefore requires further study.

\section{CONCLUSIONS}

$\mathrm{AgGaSe}_{2}$ has been investigated as an absorber in thin-film solar cells. With a band gap of $1.78 \mathrm{eV}$, it could be an interesting material as a top cell in a tandem device. A major challenge of the compound is, however, that the extension of the singlephase region of the chalcopyrite phase is very limited. It is therefore practically difficult to form absorbers free of either $\mathrm{AgGa}_{5} \mathrm{Se}_{8}$ or $\mathrm{Ag}_{9} \mathrm{GaSe}_{6}$ phases. In order to identify the presence of secondary phases, references with the corresponding compositions were synthesized and characterized. It was realized that all the phases formed during the co-evaporation were distinguishable by XRD, while Raman spectroscopy was unsuited to identify $\mathrm{Ag}_{9} \mathrm{GaSe}_{6}$ and $\mathrm{Ag}_{2} \mathrm{Se}$. Extreme sensitivity to laser irradiation and air exposure complicated Raman measurements further. For demonstration purposes, devices containing either $\mathrm{Ag}_{9} \mathrm{GaSe}_{6}$ or $\mathrm{AgGa}_{5} \mathrm{Se}_{8}$ were fabricated. Devices containing $\mathrm{Ag}_{9} \mathrm{GaSe}_{6}$ inclusions extending through the entire film (Ag-rich sample) were shunted when illuminated. The behavior of Ag-poor devices was strongly dependent on the distribution of the segregated $\mathrm{AgGa}_{5} \mathrm{Se}_{8} \mathrm{OVC}$ grains. When the absorber was grown with a three-stage process, the $\mathrm{AgGa}_{5} \mathrm{Se}_{8}$ phase covered both the front and back surfaces with quasi-continuous layers, resulting in a severe barrier for carrier transport in the device. When the absorber was deposited with a one-stage process, the $\mathrm{AgGa}_{5} \mathrm{Se}_{8}$ phase was located in laterally separated spots and often extended through the entire film thickness. As a result, these devices were not blocked and a record efficiency for $\mathrm{AgGaSe}_{2}$ of $5.8 \%$ was achieved. 


\section{ASSOCIATED CONTENT}

\section{(3) Supporting Information}

The Supporting Information is available free of charge at https://pubs.acs.org/doi/10.1021/acsaem.0c02909.

XRD of reference samples, optical properties of reference samples, Raman spectra of reference samples, investigation of photoinduced reactions, electrical properties of reference samples, band gap determination of $\mathrm{AgGaSe}_{2}$, detection of OVC in Ag-poor samples by $\mathrm{XRD}$, microstructure of devices, and discussion of FIB/ TEM artifacts (PDF)

\section{AUTHOR INFORMATION}

\section{Corresponding Author}

Jes K. Larsen - Division of Solar Cell Technology, Department of Materials Science and Engineering, Uppsala University, 75236 Uppsala, Sweden; (1) orcid.org/0000-0002-73924701; Email: jes.larsen@angstrom.uu.se

\section{Authors}

Olivier Donzel-Gargand - Division of Solar Cell Technology, Department of Materials Science and Engineering, Uppsala University, 75236 Uppsala, Sweden; ㅇo이.org/00000002-2101-3746

Kostiantyn V. Sopiha - Division of Solar Cell Technology, Department of Materials Science and Engineering, Uppsala University, 75236 Uppsala, Sweden

Jan Keller - Division of Solar Cell Technology, Department of Materials Science and Engineering, Uppsala University, 75236 Uppsala, Sweden

Kristina Lindgren - Division of Microstructure Physics, Department of Physics, Chalmers University of Technology, 41296 Göteborg, Sweden

Charlotte Platzer-Björkman - Division of Solar Cell Technology, Department of Materials Science and Engineering, Uppsala University, 75236 Uppsala, Sweden; ○ orcid.org/0000-0002-6554-9673

Marika Edoff - Division of Solar Cell Technology, Department of Materials Science and Engineering, Uppsala University, 75236 Uppsala, Sweden

Complete contact information is available at: https://pubs.acs.org/10.1021/acsaem.0c02909

\section{Notes}

The authors declare no competing financial interest.

\section{ACKNOWLEDGMENTS}

Funding from the Swedish Research Council and the Swedish Foundation for Strategic Research (grant no. RMA15-0030) is gratefully acknowledged. Part of the characterization was performed in the Chalmers Materials Analysis Laboratory (CMAL). Andrea Fazi at Chalmers is acknowledged for help with specimen preparation of the three-stage Ag-poor $\mathrm{AgGaSe}_{2}$ sample, and Dr Olof Bäcke for help and discussion with some of the STEM-EDS measurements.

\section{REFERENCES}

(1) Nakamura, M.; Yamaguchi, K.; Kimoto, Y.; Yasaki, Y.; Kato, T.; Sugimoto, H. Cd-Free $\mathrm{Cu}(\mathrm{In}, \mathrm{Ga})(\mathrm{Se}, \mathrm{S})_{2}$ Thin-Film Solar Cell With Record Efficiency of 23.35\%. IEEE J. Photovoltaics 2019, 9, 18631867.
(2) Leijtens, T.; Bush, K. A.; Prasanna, R.; McGehee, M. D. Opportunities and Challenges for Tandem Solar Cells Using Metal Halide Perovskite Semiconductors. Nat. Energy 2018, 3, 828-838.

(3) Patel, S. M.; Kapale, V. G. Optical Properties of $\mathrm{AgGaSe}_{2}$ Thin Films. Thin Solid Films 1987, 148, 143-148.

(4) Jayaraman, A.; Narayanamurti, V.; Kasper, H. M.; Chin, M. A.; Maines, R. G. Pressure Dependence of the Energy Gap in Some I-III$\mathrm{VI}_{2}$ Compound Semiconductors. Phys. Rev. B: Solid State 1976, 14, $3516-3519$

(5) Keller, J.; Sopiha, K. V.; Stolt, O.; Stolt, L.; Persson, C.; Scragg, J. J. S.; Törndahl, T.; Edoff, M. Wide-Gap (Ag,Cu)(In,Ga)Se2 Solar Cells with Different Buffer Materials-A Path to a Better Heterojunction. Prog. Photovoltaics Res. Appl. 2020, 28. DOI: $10.1002 /$ pip.3232.

(6) Murthy, Y. S.; Naidu, B. S.; Reddy, P. J. Optical Absorption of Single Phase $\mathrm{AgGaSe}_{2}$ Thin Films. Vacuum 1990, 41, 1448-1450.

(7) Yamada, K.; Hoshino, N.; Nakada, T. Crystallographic and Electrical Properties of Wide Gap $\mathrm{Ag}\left(\mathrm{In}_{1-x}, \mathrm{Ga}_{\mathrm{x}}\right) \mathrm{Se}_{2}$ Thin Films and Solar Cells. Sci. Technol. Adv. Mater. 2006, 7, 42-45.

(8) Nakada, T.; Yamada, K.; Arai, R.; Ishizaki, H.; Yamada, N. Novel Wide-Band-Gap $\mathrm{Ag}\left(\mathrm{In}_{1-\mathrm{x}} \mathrm{Ga}_{\mathrm{x}}\right) \mathrm{Se}_{2}$ Thin Film Solar Cells. MRS Online Proc. Libr. 2004, 865, 111.

(9) Xianfeng, Z.; Kobayashi, T.; Kurokawa, Y.; Miyajima, S.; Yamada, A. Deposition of $\mathrm{Ag}(\mathrm{In}, \mathrm{Ga}) \mathrm{Se}_{2}$ Solar Cells by a Modified Three-Stage Method Using a Low-Temperature-Deposited Ag-Se Cap Layer. Jpn. J. Appl. Phys. 2013, 52, 055801.

(10) Zhang, X.; Zhuang, D.; Zhang, L.; Zheng, M.; Wang, Y. Improvement of $\mathrm{Ag}(\mathrm{In}, \mathrm{Ga}) \mathrm{Se}_{2} / \mathrm{Mo}$ Interface and Solar Cell Performance by Preselenization of the Mo Back Contact. IEEE J. Photovoltaics 2020, 10, 1900-1907.

(11) Zhang, X.; Kobayashi, M.; Yamada, A. Comparison of $\mathrm{Ag}(\mathrm{In}, \mathrm{Ga}) \mathrm{Se}_{2} / \mathrm{Mo}$ and $\mathrm{Cu}(\mathrm{In}, \mathrm{Ga}) \mathrm{Se}_{2} / \mathrm{Mo}$ Interfaces in Solar Cells. ACS Appl. Mater. Interfaces 2017, 9, 16215-16220.

(12) Xianfeng, Z.; Kobayashi, T.; Kurokawa, Y.; Tashiro, Y.; Ohtsuka, M.; Yamada, T.; Yamada, A. Comparison of Interface Characterization between $\mathrm{Ag}(\mathrm{In}, \mathrm{Ga}) \mathrm{Se}_{2}$ and $\mathrm{Cu}(\mathrm{In}, \mathrm{Ga}) \mathrm{Se}_{2}$ Solar Cells by High-Angle-Annular Dark-Field Scanning Transmission Electron Microscopy. Jpn. J. Appl. Phys. 2011, 50, 126603.

(13) Xianfeng, Z.; Kobayashi, T.; Kurokawa, Y.; Yamada, A. Growth of $\mathrm{Ag}(\mathrm{In}, \mathrm{Ga}) \mathrm{Se}_{2}$ Films by Modified Three-Stage Method and Influence of Annealing on Performance of Solar Cells. Jpn. J. Appl. Phys. 2012, 51, 10NC05.

(14) Umehara, T.; Nakada, K.; Yamada, A. Impact of Roll-overShaped Current-Voltage Characteristics and Device Properties of $\mathrm{Ag}(\mathrm{In}, \mathrm{Ga}) \mathrm{Se}_{2}$ Solar Cells. Jpn. J. Appl. Phys. 2016, 56, 012302.

(15) Zhang, X.; Kobayashi, M. Effect of Sodium on the Properties of $\mathrm{Ag}$ (In, Ga) $\mathrm{Se}_{2}$ Thin Films and Solar Cells. IEEE J. Photovoltaics 2017, 7, 1426-1432.

(16) Byer, R. L.; Choy, M. M.; Herbst, R. L.; Chemla, D. S.; Feigelson, R. S. Second Harmonic Generation and Infrared Mixing in AgGaSe 2 . Appl. Phys. Lett. 1974, 24, 65-68.

(17) Catella, G. C.; Shiozawa, L. R.; Hietanen, J. R.; Eckardt, R. C.; Route, R. K.; Feigelson, R. S.; Cooper, D. G.; Marquardt, C. L. MidIR Absorption in $\mathrm{AgGaSe}_{2}$ Optical Parametric Oscillator Crystals. Appl. Opt. 1993, 32, 3948-3951.

(18) Iseler, G. W. Thermal Expansion and Seeded Bridgman Growth of $\mathrm{AgGaSe}_{2}$. J. Cryst. Growth 1977, 41, 146-150.

(19) Kim, N.-H.; Feigelson, R. S.; Route, R. K. Surface Migration and Volume Diffusion in the $\mathrm{AgGaSe}_{2}-\mathrm{Ag}_{2} \mathrm{Se}$ System. J. Mater. Res. 1992, 7, 1215-1220.

(20) Mikkelsen, J. C. $\mathrm{Ag}_{2} \mathrm{Se}_{-} \mathrm{Ga}_{2} \mathrm{Se}_{3}$ Pseudobinary Phase Diagram. Mater. Res. Bull. 1977, 12, 497-502.

(21) Route, R. K.; Feigelson, R. S.; Raymakers, R. J. Growth of $\mathrm{AgGaSe}_{2}$ for Infrared Applications. J. Cryst. Growth 1974, 24-25, 390-395.

(22) Ishizaki, H.; Yamada, K.; Arai, R.; Kuromiya, Y.; Masatsugu, Y.; Yamada, N.; Nakada, T. Structural Properties of Ag-Based Chalcopyrite Compound Thin Films for Solar Cells. MRS Online Proc. Libr. 2004, 865, 512. 
(23) Rincón, C.; Wasim, S. M.; Marín, G.; Delgado, J. M.; Huntzinger, J. R.; Zwick, A.; Galibert, J. Raman Spectra of the Ordered Vacancy Compounds $\mathrm{CuIn}_{3} \mathrm{Se}_{5}$ and $\mathrm{CuGa}_{3} \mathrm{Se}_{5}$. Appl. Phys. Lett. 1998, 73, 441-443.

(24) Xu, C.-M.; Huang, W.-H.; Xu, J.; Yang, X.-J.; Zuo, J.; Xu, X.-L.; Liu, H.-T. Defect-Induced Structural Disorder in Tetragonal $\mathrm{Cu}-$ $\left(\mathrm{In}_{1-\mathrm{x}} \mathrm{Ga}_{\mathrm{x}}\right)_{5} \mathrm{Se}_{8}$ Thin Films Investigated by Raman Spectroscopy: The Effect of Ga Addition. J. Phys.: Condens. Matter 2004, 16, 4149-4155.

(25) Lehmann, S.; Marrón, D. F.; León, M.; Feyerherm, R.; Dudzik, E.; Friedrich, E. J.; Tovar, M.; Tomm, Y.; Wolf, C.; Schorr, S.; Schedel-Niedrig, T.; Lux-Steiner, M. C.; Merino, J. M. Long-Range Structure of $\mathrm{Cu}\left(\mathrm{In}_{1-\mathrm{x}} \mathrm{Ga}_{\mathrm{x}}\right)_{3} \mathrm{Se}_{5}$ : A Complementary Neutron and Anomalous X-Ray Diffraction Study. J. Appl. Phys. 2011, 109, 013518.

(26) Haubold, E.; Schöppe, P.; Eckner, S.; Lehmann, S.; Colantoni, I.; d'Acapito Acapito, F.; di Benedetto, F.; Schorr, S.; Schnohr, C. S. Short-Range versus Long-Range Structure in $\mathrm{Cu}(\mathrm{In}, \mathrm{Ga}) \mathrm{Se}_{2}, \mathrm{Cu}$ $(\mathrm{In}, \mathrm{Ga})_{3} \mathrm{Se}_{5}$, and $\mathrm{Cu}(\mathrm{In}, \mathrm{Ga})_{5} \mathrm{Se}_{8}$. J. Alloys Compd. 2019, 774, 803812.

(27) Boehnke, U.-C.; Kühn, G. Phase Relations in the Ternary System Cu-In-Se. J. Mater. Sci. 1987, 22, 1635-1641.

(28) Benoit, P.; Charpin, P.; Djega-Mariadassou, C. Composes Definis dans le Systeme Ag-In-Se Structure Cristalline de $\mathrm{AgIn}_{5} \mathrm{Se}_{8}$. Mater. Res. Bull. 1983, 18, 1047-1057.

(29) Yarema, O.; Yarema, M.; Bozyigit, D.; Lin, W. M. M.; Wood, V. Independent Composition and Size Control for Highly Luminescent Indium-Rich Silver Indium Selenide Nanocrystals. ACS Nano 2015, 9, 11134-11142.

(30) Lübbers, D.; Leute, V. The Crystal Structure of $\beta-\mathrm{Ga}_{2} \mathrm{Se}_{3}$. J. Solid State Chem. 1982, 43, 339-345.

(31) Tyrziu, M. P.; Radautsan, S. I.; Markus, M. M.; Kolosenko, S. M. State Diagram of CdSe- $-\mathrm{Ga}_{2} \mathrm{Se}_{3}$. Phys. Status Solidi A 1970, 3, K293-K296.

(32) Yamada, A.; Kojima, N.; Takahashi, K.; Okamoto, T.; Konagai, M. Raman Study of Epitaxial $\mathrm{Ga}_{2} \mathrm{Se}_{3}$ Films Grown by Molecular Beam Epitaxy. Jpn. J. Appl. Phys. 1992, 31, L186.

(33) Okamoto, T.; Yamada, A.; Konagai, M.; Takahashi, K. Polarized Photoluminescence in Vacancy-Ordered $\mathrm{Ga}_{2} \mathrm{Se}_{3}$. J. Cryst. Growth 1994, 138, 204-207.

(34) Takumi, M.; Ueda, T.; Koshio, Y.; Nishimura, H.; Nagata, K. Optical Properties of $\mathrm{Ga}_{2} \mathrm{Se}_{3}$ under High Pressure. Phys. Status Solidi B 2001, 223, 271-274.

(35) Singh, N. B.; Hopkins, R. H.; Feichtner, J. D. Effect of Annealing on the Optical Quality of $\mathrm{AgGaS}_{2}$ and $\mathrm{AgGaSe}_{2}$ Single Crystals. J. Mater. Sci. 1986, 21, 837-841.

(36) Cui, Y.; Roy, U. N.; Bhattacharya, P.; Parker, A.; Burger, A.; Goldstein, J. T. Raman Spectroscopy Study of $\mathrm{AgGaSe}_{2}$, $\mathrm{AgGa}_{0.9} \mathrm{In}_{0.1} \mathrm{Se}_{2}$, and $\mathrm{AgGa}_{0.8} \mathrm{In}_{0.2} \mathrm{Se}_{2}$ Crystals. Solid State Commun. 2010, 150, 1686-1689.

(37) van der Ziel, J. P.; Meixner, A. E.; Kasper, H. M.; Ditzenberger, J. A. Lattice Vibrations of $\mathrm{AgGaS}_{2}, \mathrm{AgGaSe}_{2}$, and $\mathrm{CuGaS}_{2}$. Phys. Rev. B: Solid State 1974, 9, 4286-4294.

(38) Deloume, J. P.; Faure, R.; Loiseleur, H.; Roubin, M. Structure Cristalline de La Phase $\mathrm{Ag}_{9} \mathrm{GaSe}_{6}$. Acta Crystallogr., Sect. B: Struct. Crystallogr. Cryst. Chem. 1978, 34, 3189-3193.

(39) Lin, S.; Li, W.; Li, S.; Zhang, X.; Chen, Z.; Xu, Y.; Chen, Y.; Pei, Y. High Thermoelectric Performance of $\mathrm{Ag}_{9} \mathrm{GaSe}_{6}$ Enabled by Low Cutoff Frequency of Acoustic Phonons. Joule 2017, 1, 816-830.

(40) Yu, J.; Yun, H. Reinvestigation of the Low-Temperature Form of $\mathrm{Ag}_{2} \mathrm{Se}$ (Naumannite) Based on Single-Crystal Data. Acta Crystallogr., Sect. E: Struct. Rep. Online 2011, 67, i45.

(41) Rahlfs, P. Über Die Kubischen Hochtemperaturmodifikationen Der Sulfide, Selenide Und Telluride Des Silbers Und Des Einwertigen Kupfers. Z. Phys. Chem. 1936, 31, 157-194.

(42) Naumov, P.; Barkalov, O.; Mirhosseini, H.; Felser, C.; Medvedev, S. A. Atomic and Electronic Structures Evolution of the Narrow Band Gap Semiconductor $\mathrm{Ag}_{2} \mathrm{Se}$ under High Pressure. J. Phys.: Condens. Matter 2016, 28, 385801.
(43) Genovese, L.; Cocchiara, C.; Piazza, S.; Sunseri, C.; Inguanta, R. Electrochemical Deposition of $\mathrm{Ag}_{2} \mathrm{Se}$ Nanostructures. Mater. Res. Bull. 2017, 86, 10-18.

(44) Dalven, R.; Gill, R. Energy Gap in Beta- $\mathrm{Ag}_{2}$ Se. Phys. Rev. 1967, $159,645-649$.

(45) Tansho, M.; Wada, H.; Ishii, M.; Onoda, Y. Silver Ionic Conductor $\mathrm{Ag}_{8} \mathrm{GaSe}_{6}$ Studied by $\mathrm{Ag}$ and Ga NMR. Solid State Ionics 1996, 86-88, 155-158.

(46) Olekseyuk, I. D.; Krykhovets, O. V. The $\mathrm{Ag}_{2} \mathrm{Se}-\mathrm{In}_{2} \mathrm{Se}_{3}-\mathrm{SnSe}_{2}$ System. J. Alloys Compd. 2001, 316, 193-202.

(47) Salomé, P. M. P.; Fjällström, V.; Szaniawski, P.; Leitão, J. P.; Hultqvist, A.; Fernandes, P. A.; Teixeira, J. P.; Falcão, B. P.; Zimmermann, U.; da Cunha, A. F.; Edoff, M. A Comparison between Thin Film Solar Cells Made from Co-Evaporated $\mathrm{CuIn}_{1-\mathrm{x}} \mathrm{Ga}_{\mathrm{X}} \mathrm{Se}_{2}$ Using a One-Stage Process versus a Three-Stage Process. Prog. Photovoltaics Res. Appl. 2015, 23, 470-478.

(48) Ren, Y.; Scragg, J. J.; Ericson, T.; Kubart, T.; Platzer-Björkman, C. Reactively Sputtered Films in the $\mathrm{Cu}_{\mathrm{x}} \mathrm{S}-\mathrm{ZnS}-\mathrm{SnS}_{\mathrm{y}}$ System: From Metastability to Equilibrium. Thin Solid Films 2015, 582, 208-214.

(49) Insignares-Cuello, C.; Broussillou, C.; Bermúdez, V.; Saucedo, E.; Pérez-Rodríguez, A.; Izquierdo-Roca, V. Raman Scattering Analysis of Electrodeposited $\mathrm{Cu}(\mathrm{In}, \mathrm{Ga}) \mathrm{Se}_{2}$ Solar Cells: Impact of Ordered Vacancy Compounds on Cell Efficiency. Appl. Phys. Lett. 2014, 105, 021905.

(50) Samal, A. K.; Pradeep, T. Room-Temperature Chemical Synthesis of Silver Telluride Nanowires. J. Phys. Chem. C 2009, 113, 13539-13544.

(51) Qin, A.; Fang, Y.; Tao, P.; Zhang, J.; Su, C. Silver Telluride Nanotubes Prepared by the Hydrothermal Method. Inorg. Chem. 2007, 46, 7403-7409.

(52) Pandiaraman, M.; Soundararajan, N. Micro-Raman Studies on Thermally Evaporated $\mathrm{Ag}_{2} \mathrm{Se}$ Thin Films. J. Theor. Appl. Phys. 2012, 6, 7.

(53) Kojima, N.; Yamada, A.; Takahashi, K.; Okamoto, T.; Konagai, M.; Saito, K. Photoinduced Oxidation of Epitaxial $\mathrm{Ga}_{2} \mathrm{Se}_{3}$ Grown by Molecular Beam Epitaxy. Jpn. J. Appl. Phys. 1993, 32, L887.

(54) Grossberg, M.; Krustok, J.; Bodnar, I.; Siebentritt, S.; Albert, J. Photoluminescence and Raman Spectra of the Ordered Vacancy Compound $\mathrm{CuGa}_{5} \mathrm{Se}_{8}$. Phys. B 2008, 403, 184-189.

(55) Neumann, H. Lattice Vibrations in A(I) B(III) $\mathrm{C}_{2}(\mathrm{VI})$ Chalcopyrite Compounds. Helv. Phys. Acta 1985, 58, 337-346.

(56) Jiang, B.; Qiu, P.; Chen, H.; Zhang, Q.; Zhao, K.; Ren, D.; Shi, X.; Chen, L. An Argyrodite-Type $\mathrm{Ag}_{9} \mathrm{GaSe}_{6}$ Liquid-like Material with Ultralow Thermal Conductivity and High Thermoelectric Performance. Chem. Commun. 2017, 53, 11658-11661.

(57) Qi, X.; Chen, J.; Guo, K.; He, S.; Yang, J.; Li, Z.; Xing, J.; Hu, J.; Luo, H.; Zhang, W.; Luo, J. Thermal Stability of $\mathrm{Ag}_{9} \mathrm{GaSe}_{6}$ and Its Potential as a Functionally Graded Thermoelectric Material. Chem. Eng. J. 2019, 374, 494-501.

(58) Keller, J.; Stolt, L.; Sopiha, K. V.; Larsen, J. K.; Riekehr, L.; Edoff, M. On the Paramount Role of Absorber Stoichiometry in $(\mathrm{Ag}, \mathrm{Cu})(\mathrm{In}, \mathrm{Ga}) \mathrm{Se}_{2}$ Wide-Gap Solar Cells. Sol. RRL 2020, 4, 2000508.

(59) Sharan, A.; Sabino, F. P.; Janotti, A.; Gaillard, N.; Ogitsu, T.; Varley, J. B. Assessing the Roles of $\mathrm{Cu}$ - and Ag-Deficient Layers in Chalcopyrite-Based Solar Cells through First Principles Calculations. J. Appl. Phys. 2020, 127, 065303.

(60) Herberholz, R.; Rau, U.; Schock, H. W.; Haalboom, T.; Gödecke, T.; Ernst, F.; Beilharz, C.; Benz, K. W.; Cahen, D. Phase Segregation, $\mathrm{Cu}$ Migration and Junction Formation in $\mathrm{Cu}(\mathrm{In}, \mathrm{Ga}) \mathrm{Se}_{2}$. Eur. Phys. J.: Appl. Phys. 1999, 6, 131-139.

(61) Tanaka, T.; Demizu, Y.; Yoshida, A.; Yamaguchi, T. Preparation of $\mathrm{Cu}(\mathrm{In}, \mathrm{Ga})_{2} \mathrm{Se}_{3.5}$ Thin Films by Radio Frequency Sputtering from Stoichiometric $\mathrm{Cu}(\mathrm{In}, \mathrm{Ga}) \mathrm{Se}_{2}$ and $\mathrm{Na}_{2} \mathrm{Se}$ Mixture Target. J. Appl. Phys. 1997, 81, 7619-7622.

(62) Sopiha, K. V.; Larsen, J. K.; Donzel-Gargand, O.; Khavari, F.; Keller, J.; Edoff, M.; Platzer-Björkman, C.; Persson, C.; Scragg, J. J. S. Thermodynamic Stability, Phase Separation and Ag Grading in $(\mathrm{Ag}, \mathrm{Cu})(\mathrm{In}, \mathrm{Ga}) \mathrm{Se}_{2}$ Solar Absorbers. J. Mater. Chem. A 2020, 8, 8740-8751. 